\title{
E-Waqfuna System Development: Management Solutions for Productive Waqf Asset Management in the Digital Age
}

\author{
Nurul Iman ${ }^{1}$ Adi Santoso ${ }^{2}$ Edi Kurniawan ${ }^{3}$ \\ cahayaiman66@gmail.com¹, adisantoso@umpo.ac.id², edy@umpo.ac.id ${ }^{3}$ \\ Universitas Muhammadiyah Ponorogo $0^{1,2,3}$
}

\begin{abstract}
This paper examines the development of administrative management systems and productive waqf assets online through the e-waqfuna system for nadzir. Problems relating to the management of administrative and waqf assets are currently caused by management processes that are still carried out manually or offline. In the digital era, access is needed to make it easier for the community to conduct waqf activities as well as easier and more effective management of waqf assets and assets. The development of appropriate technology to overcome these problems is through online waqfuna information and asset management systems, e-waqfuna. Through the e-waqfuna system some users will have different access rights (multiuser). There are two groups of users who can access it namely users who have access to manage data in the system. This user has broad access rights, which can enter data, process data and display data based on the interests of users who need it. The second user is a public user, i.e. general user who can view waqf information from another computer. The information displayed and can be seen by this user, of course, must be knowledgeable or get permission from the user system manager and waqf administration.
\end{abstract}

Keywords:waqf, information system, digital age..

\section{Pendahuluan}

Di era digitalisasi saat ini diperlukan pengelolaan yang tepat untuk mengembangkan teknologi yang mengelola dan memudahkan masyarakat untuk melakukan administrasi wakaf. Penggunaan Platform digital diharapkan mampu menjadi solusi dalam melakukan pengelolaan administrasi wakaf yang mudah dan efisien.

Di Ponorogo terdapat beberapa lembaga yang dapat dianggap berhasil mengembangkan pengalolaan wakaf secara produktif, seperti halnya Pondok Gontor Ponorogo dan Pengurus Daerah Muhamamdiyah (melalui majelis terkait, majelis ekonomi dan majelis wakaf). Pengurus Daerah Muhammadiyah Ponorogo telah memiliki berbagai amal usaha seperti rumah sakit, supermarket, bank syariah, panti asuhan, pondok pesantren, sekolah dan madrasah, dan lainnya baik yang dijalankan sendiri maupun yang dioperasionalkan oleh cabang maupun ranting di bawahnya. Aset tanah yang dimiliki sebanyak 522 bidang, terdiri atas 474 tanah wakaf, dan 48 tanah non wakaf [1]. Sementara itu, Pondok Modern Darussalam Gontor (PMDG) yang didirikan sejak tahun 1926, berusaha untuk mengelola sumberdaya wakaf dan assetasetnya ditangani secara serius. Tidak berlebihan jika pesantren ini dianggap salah satu dari sedikit lembaga pendidikan pesantren yang dinilai berhasil mengelola wakaf secara baik. 
Menurut Bakar [2], berbagai studi yang ada menyimpulkan bahwa pengelolaan wakaf di PMDG telah menunjukkan hasil yang positif untuk kepentingan umum dan kemajuan masyarakat. Kesuksesan Pondok Modern Gontor dalam mengelola wakaf ditengarai disebabkan oleh kesuksesannya dalam memilih strategi dan manajemen aset secara baik. Bakar menyebut dua hal: pertama, pengelola wakaf Pondok Modern Gontor telah berbadan hukum; kedua, strategi pemanfaatan hasil wakaf lebih diorientasikan untuk tujuan produktif ketimbang konsumtif. Kesuksesan penataan wakaf di Pondok Gontor memberikan inspirasi bagi pesantren-pesantren lain di Ponorogo dan tanah air ini termasuk pesantren Darul Fikri Bringin Kauman Ponorogo.

Namun, dalam studi lapangan ditemukan bahwa pesantren sekaliber Gontor "cukup kesulitan" untuk melakukan penataan adminstrasi terhadap aset-aset pondok yang terus berkembang. Laju pertumbuhan harta benda Pondok yang notabene merupakan wakaf dan hasil wakaf tidak diimbangi dengan adanya sistem administrasi yang mampu mencakup kebutuhan pendataan dan administrasi wakaf dan asetnya. Realita penataan administrasi wakaf pesantren dan asetnya di luar pesantren Gontor akan lebih memprihatinkan sebagaimana ditegaskan sekretaris Forum Nadzir Wakaf Ponorogo , Ahmad Muslich. Menurut Bakar [1], lembagalembaga wakaf atau nadzir wakaf, khususnya pesantren, perlu mendapatkan bantuan berkenaan dengan penataaan dan administrasi aset yang dimiliki.

Selain belum mendapatkan porsi yang semestinya, pengelolaan wakaf di pesantren berjalan secara "alami" dan belum produktif. Proses administrasi aset masih berjalan manual, dalam pengertian aset wakaf dicatat dan dibukukukan dalam buku induk tertentu, dan buktibukti kepemilikan dan status tanah wakaf diarsipkan dalam brankas khusus.

Pada penataan dan pendataan aset lazim pula digunakan program Microsoft Excell yang berusaha dan menyajikan dapat menyajikan data rekap sementara. Dalam berbagai kesempatan, ketika terdapat tuntutan out data atau laporan tertulis, pemenuhan terhadap permohonan ini belum dapat direspons secara cepat dan akurat.

Tuntutan terhadap administrasi dan manajemen aset wakaf secara baik juga telah didorong oleh pemerintah khususnya Kementerian Agama dengan menggulirkan Sistem Informasi Wakaf (SIWAK). Sistem ini menjadi semacam data berjalan tentang jumlah wakaf secara nasional dengan operator yang memasukkan data wakaf dari setiap kecamatan. Hanya saja, sistem ini khusus diberlakukan bagi institusi pemerintah dan tidak mengakomodasi penataan data di tingkat lembaga pengelola wakaf atau nadzir yang seringkali lebih mengalami kesulitan melakukan administrasi terhadap aset-aset wakaf yang dimiliki lembaga.

Berdasarkan fenomena permasalahan tersebut, dibangunlah konsep sistem SIMAWAK Waqfuna (e-waqfuna). Melalui sistem SIMAWAK Waqfuna (e-waqfuna) ini, diharapkan bahwa permasalahan administrasi dan manajemen aset wakaf dapat diselesaikan.

\section{Pembahasan}

\subsection{Wakaf Produktif}

Wakaf merupakan tindakan wakif dalam melakukan penyerahan aset harta bendanya secara suka rela dengan tujuan ibadah dan untuk kepentingan ummat. Aset atau harta benda wakaf sesuai dengan Pasal 16 UU Nomor 41 Tahun 2004 dapat berupa benda tidak bergerak (fixed asset) dan benda bergerak. Harta tidak bergerak meliputi : 1) hak atas tanah; 2) bangunan atau bagian dari bangunan; c) tanaman dan benda lain yang berkaitan dengan tanah; d) hak milik atas satuan rumah susun; e) benda tidak bergerak lain sesuai dengan ketentuan syariah dan 
peraturan perundang-undangan yang berlaku. Sementara itu, yang dimaksud benda bergerak adalah harta yang tidak dapat habis karena dikonsumsi, meliputi : a) uang; b) logam mulia; d) surat berharga; e). kendaraan; f) hak atas kekayaan intelektual; g) hak sewa; h) benda bergerak lain sesuai dengan ketentuan syariah dan peaturan perundang-undangan yang berlaku [1]. Menurut Mubarok [3], wakaf produktif adalah proses pengelolaan aset wakaf dalam menghasilkan barang dan jasa.

\subsection{Nadzir}

Nadzir diartikan sebagai pihak yang berperan sebagai penjaga, pemelihara, pengelola dan pengawas [1]. Menurut terminologi fikih, nadzir diartikan sebagai orang atau lembaga yang diamanati suatu kekuasaan serta kewajiban untuk melakukan pengelolaan dan pemeliharaan aset wakaf [4]. Nadzir merupakan pihak yang menerima aset wakaf dari pihak wakif dengan tanggung jawab untuk melakukan pengelolaan atas aset wakaf tersebut. Pihak nadzir adalah pihak yang paling dominan dalam seluruh proses wakaf. Pihak - pihak lain yang terlibat dalam proses wakaf tidak memiliki wewenang untuk melakukan proses pengelolaan wakaf. Oleh sebab itu, nadzir menjadi faktor yang paling dominan sebab memiliki wewenang dalam mengelola wakaf.

Berdasarkan Undang-Undang Nomor 41 tahun 2004 pasal 9 dijelaskan bahwa terdapat tiga jenis nadzir yakni perorangan, organisasi dan badan hukum. Ada beberapa syarat yang harus terpenuhi untuk menjadi nadzir perorangan di Indonesia meliputi [1]; 1) WNI, 2) islam, 3) dewasa, 4) amanah, 5) sehat jasmani dan rohani, 6) tidak melakukan perbuatan melanggar hukum.

Organisasi diperbolehkan menjadi pihak nadzir ketika memenuhi persyaratan berikut ini : 1) Pengurus organisasi telah memnuhi syarat nadzir perorangan, 2) Bergerak dibidang sosial, bidang agama islam dan bidang pendidikan islam [5]. Badan hukum yang ingin menjadi nadzir harus memenuhi persyaratan- persyaratan berikut ini; 1) pengurus badan hukum telah memenuhi persyaratan menjadi nadzir perorangan, 2) badan hukum yang dibentuk telah sesuai dengan UU yang berlaku, 3) badan hukum bergerak dibidang sosial, pendidikan dan bidang keagamaan islam [6]

Tugas nadzir di Indonesia telah diatur oleh Undang-Undang nomor 41 tahun 2004 pasal 11 tentang pengelolaan wakaf. Tugas nadzir adalah sebagai berikut; 1) melakukan pengelolaan administrasi aset wakaf, 2) melakukan pengelolaan dan pengembangan aset wakaf sesuai dengan peruntukannya, 3) melakukan pengawasan dan pemeliharaan atas aset wakaf[7].

Kewajiban yang harus dilaksanakan nadzir telah diatur dalam pasal 220 pada kompilasi hukum islam sebagai berikut : 1) kewajiban untuk mengelola dan bertanggung jawab atas aset wakaf serta pelaksanaan pengembangan aset wakaf sesuai peruntukannya, 2) kewajiban untuk membuat laporan pengelolaan aset wakaf secara berkala, 3) kewajiban untuk membuat laporan yang sesuai dengan peraturan yang telah ditetapkan oleh Kementerian Agama Republik Indonesia [2]

\section{3 E-Waqfanu}

E-waqfanu atau sistem informasi dan manajemen wakaf (SIMAWAK) Waqfuna merupakan sebuah program sistem informasi dan manajemen aset wakaf yang berbentuk perangkat lunas dikembangkan berbasis daring (website) yang berisikan informasi mengenai aset yang telah diwakafkan. Melalui sistem informasi dan manajemen wakaf (SIMAWAK) Waqfuna akan memudahkan nadzir dalam melakukan pengelolaan aset wakaf dan pihak wakif dapat mengetahui sejauh mana pihak nadzir melakukan pengelolaan atas harta yang diwakafkannya. Sistem ini juga akan digunakan untuk melakukann pengubahan data wakaf 
seperti data yang berkaitan dengan informasi penambahan aset wakaf, penghapusan wakaf serta transaksi - transaksi lainnya.

\subsection{Implementasi}

Spesifikasi sistem informasi dan manajemen wakaf(SIMAWAK) Waqfuna yang hendak dibangun atau diimplementasikan adalah sebagai berikut:

a. Sistem Informasi dan manajemen aset wakaf ini dibangun berbasis web sehingga dengan mudah dapat diaplikasikan secara langsung dan diakses secara daring oleh beberapa pengguna yang memiliki hak akses yang berbeda (multiuser).

b. Pengguna yang menggunakan sistem ini dibagi menjadi dua hak akses, yaitu pengguna yang memiliki akses untuk mengelola data dalam sistem. Pengguna ini memiliki hak akses yang luas, yaitu dapat memasukkan data, mengolah data dan menampilkan data berdasarkan kepentingan pengguna yang membutuhkan.

c. Pengguna yang kedua adalah pengguna publik, yaitu pengguna umum yang dapat melihat informasi wakaf dari komputer lain. Informasi yang ditampilkan dan dapat dilihat oleh pengguna ini, tentunya harus sepengetahuan atau mendapatkan izin dari pengguna pengelola sistem dan administrasi wakaf.

d. Sistem informasi ini memiliki fungsi pengolahan data dari input yang dilakukan, pengguna diolah, dan disajikan dalam bentuk informasi yang sistematis dan terstruktur.

e. Keluaran dalam bentuk: softcopy dan hardcopy (apabila dibutuhkan bentuk cetak)

f. Sistem ini juga dapat menyimpan data dari hardcopy menjadi softcopy yang berfungsi sebagai arsip digital (bukti kepemilikan)

g. Sistem ini dibangun dengan orientasi dapat mutakhirkan sesuai dengan kebutuhan administrasi dan manajemen wakaf yang terus berkembang.

Sistem informasi dan manajemen wakaf ini memiliki fitur backup atau eksport data untuk mengantisipasi kehilangan data atau kesalahan pengguna pada saat mengoperasikan sistem. Dengan adanya data backup, data yang hilang dapat dikembalikan dengan mudah

\section{Kesimpulan}

Tugas nadzir wakaf adalah melakukan administrasi aset atau harta benda wakaf dalam rangka pengamanan dan lindungan aset karena sifat harta wakaf (mauquf) harus abadi demi kemanfatan manfaat wakaf. Jika diselenggarakan dengan baik, akan menunjang upaya pengembangan aset sekaligus menjaga amanah para wakif lewat transparansi pengelolaan dan pelaporan. Sayangnya kegiatan administrasi para nadzir masih sering kali berjalan manual sehingga sering menghambat tujuan perwakafan tersebut. Temuan pada lembaga-lembaga pengelola wakaf di Ponorogo menunjukkan hal tersebut. Oleh sebab itu, diperlukan solusi alternatif atas permasalahan permasalahan tersebut. Langkah-langkah yang akan ditempuh dalam pendampingan ini meliputi sosialisasi program, FGD untuk need assessment pembangunan sistem, pembangunan sistem (SIMAWAK Waqfuna), pengembangan e-waqfuna, workshop implementasi, implementasi sistem, dan evaluasi. Melalui tahapan yang panjang ini, diharapkan sistem yang dibangun dapat sesuai dengan kondisi lapangan, dan memberikan efek positif terhadap produktivitas wakaf, pengamanan aset serta terciptanya sistem daring ( $e$ waqfuna) yang dapat menggantikan tugas manual dari nadzir wakaf. 


\section{References}

[1] A. A. Budiman, Good Governance Pada Lembaga Ziswaf (Implementasi Pelibatan Pemangku Kepentingan dalam Pengelolaan Ziswaf. Semarang: Lembaga Penelitian IAIN Walisongo Semarang, 2012.

[2] M. A. Al-Kabisi, Hukum Wakaf Kajian Kontemporer Pertama dan Terlengkap tentang Fungsi dan Pengelolaan Wakaf serta Penyelesaian atas Sengketa Wakaf. Jakarta: Dompet Dhuafa Republika, 2003.

[3] J. Mubarok, Wakaf Produktif. Bandung: Simbiosa Rekatama Media, 2008.

[4] I. S. Ramli, Nihayahal Muhtaj, Juz IV. Beirut: Daaral Kitabal Alamiyah, 1996.

[5] S. Harahap, Paradikma Baru Wakaf di Indonesia. Jakarta: Direktori Pemberdayaan Direktori Jenderal Bimbingan Masyarakat Islam Departemen Agama RI, 2008.

[6] A. Rofiq, Hukum Islam Di Indonesia. Jakarta: Raja Grafindo Persada, 2013.

[7] Rozalinda, Manajemen Wakaf Produktif. Jakarta: Raja Grafindo Persada, 2015. 